\title{
Нелло Барилэ
}

Университет лингвистики и коммуникаций, Италия, г. Милан, e-mail: nello.barile@iulm.it

\section{ПАНАЕМИИ, МЕМЫ И СУВЕРЕННОЕ ОБЩЕНИЕ}

В статье анализируется связь между пандемическим распространением Covid-19 и инфодемикой, определяемой распространением мемов и других цифровых среАств, в попытке восстановить сильное чувство идентичности («суверенный» вирус). Пандемия - это не просто антитеза глобализации и неолиберальной идеологии. Фактически, это может быть дополнением к ним, указывая на другой путь развития между технологиями, потреблением и образом жизни. Это похоже на то, что имел в виду Уильям Берроуз, когАа выдвигал свою теорию языка как вируса. Слово, разработанное Берроузом, заразило биологический организм предалфавитного человека, определив его изгнание из БОГА (“Сада наслаждений»). СлеАовательно, история человеческой цивилизации читается как огромное изменение отношений межАу телом и мыслью - в том смысле, что мысль читается как сущность, чуждая телу, которая действует почти сговорчиво по отношению к нему.

Автор считает, что откровенный эффект вируса состоит не только в том, чтобы подорвать рутину экспертных систем, но и в том, что мы слишком Аолго воспринимаем социальную реальность как Аолжное.

Ключевые слова: пандемия, мемы, цивилизация, слово, «суверенный» вирус.

Nello Barile

University of Linguistics and Communications of Milan, Italy, Milan, e-mail: nello.barile@iulm.it

\section{Pandemics, Memes, and Sovereign Communication}

The article analyzes the relation between the pandemic diffusion of the Covid-19 and the infodemics determined by the proliferation of memes and other digital means, trying to restore a strong sense of identity (the "sovereignist" virus). The pandemic is not simply the antithesis of globalization and neoliberal ideology. In fact, it can be complementary to them, indicating a different path of development between technology, consumption and lifestyle. This is akin to what William Burroughs meant when he put forward his theory of language as a virus. The Word, Burroughs elaborated, infected the biological organism of pre-alphabetic man, determining his expulsion from GOD (the "Garden of Delights"). The history of human civilization is, therefore, read as a tremendous reversal of the relationship between body and thought-in the sense that thought is read as an entity alien to the body that acts almost conspiratorially with respect to it.

The author considers, that the blatant effect of the virus is not only to subvert the routines of expert systems, but our perception of social reality taken for granted for too long.

Key words: pandemic, memes, civilization, word, «sovereignist» virus.

\section{Нем^о Барилэ}

Тіл білімі және байланыс университеті, Италия, Милан к., e-mail: nello.barile@iulm.it

\section{Пандемия, мемдер және егемен байланыс}

Мақалада Ковид-19 пандемиясының пандемиялық таралуы мен мемберлер мен басқа да сандық медианың таралуымен анықталған инфодемиканың өзара жеке басының сезімін қалпына келтіру мақсатында («егемендік» вирус) байланысы қарастырылған. Пандемия - бұл жаһандану мен неолибералдық идеологияның антитезасы ғана емес. Шындығында, бұл технология, тұтыну және өмір салты арасындағы әр түрлі даму жолын көрсетіп, оларға қосымша бола алады. Бұл Уильям Берроуздың тіл теориясын вирус ретінде жетілдірген кезде айтқан нәрселеріне ұқсас. Берроуз жасаған сөз, әліпбиге лейінгі адамның биологиялық ағзасын оның ҚҰААЙдан шығарылуын анықтаған («Керемет бақ»). Аемек, аАамзат өркениетінің тарихы дене мен ойдың 
қарым-қатынасындағы орасан зор өзгеріс ретінде оқылады - бұл мағынада ой денеге бөтен зат ретінде оқылаАы, оған сәйкес келеАі.

Автор вирустың айқын әсері тек сарапшылар жүйелерінің жұмысын бұзып қана қоймайды, сонымен қатар әлеуметтік шындықты ұзақ уақыт қабылдаймыз деп санайды.

Түйін сөздер: пандемия, мемдер, өркениет, сөз, «егемендік» вирусы.

\section{Введение}

Пандемия - это не просто антитеза глобализации и неолиберальная идеология. Фактически, это может быть дополнением к ним, указывая на различный путь развития между технологиями, потреблением и образом жизни. Следует отметить, что в постпандемическом обществе действие вируса, как если бы оно было средой, имеет тенденцию изменять формы, пропорции и ритмы вращения самого общества. Откровенный эффект вируса состоит не только в том, чтобы подорвать рутину экспертных систем, но и в том, что мы слишком долго воспринимаем социальную реальность как должное. Потребление и образ жизни, которые в восприятии простого гражданина являются естественными элементами, вместо этого проявляют себя в их искусственном измерении. Во-первых, появляется мода на то, что в уединенном обществе есть польза, а для личного удовольствия более целесообразнее использовать людей и семью. Это вирус мести, который катализирует столкновение юга с севером, наших против других (которые становятся нами, когда мы выходим на улицу), молодых людей против старых. Вдохновленный реванскистским синдромом против пожилой почти кроваво-красной пшеницы (Fritz Kiersch, 1984), молодые люди опьяняются в новых вакханалах и почти рады, что новая катастрофа ни разу не затронула их, но затронула пожилых людей. Трагический враг в стране, где господствует геронтократия. Все это превращает классическую японскую оппозицию между хикикомори (Saito, 2013) и кодукоши - с одной стороны, аутистическая изоляция молодых технозависимых, с другой - смерть в одиночестве пожилых людей. Это две позитивные модели гражданственности, которые защищают других от инфекции (Barile, 2020). По этой причине ceгодня существует потребность в новом дизайне сожительства, от социального дистанцирования до искажения часов работы магазинов, что радикально меняет восприятие пространства-времени в технократических обществах. Изоляция уже была характерной чертой предпандемного общества, внедренного платформенным обще- ством и системами доставки (Barile, 2020), но теперь она стала осевым принципом организации. Такое перепрограммирование программного обеспечения, которое управляет социальными отношениями и которое каким-то образом взломано биологическим вирусом, стало почти натуралистическим восприятием организации повседневной жизни. Использование приложений, которые позволяют вам поддерживать социальное дистанцирование, таких как широко обсуждаемый Immuni, превращается в принцип геймификации или применения игровых моделей в неигровых контекстах. В очень насыщенной главе своего текста Макстей A. (McStay, $2018,44)$ обсуждает переход от повествования историй, характеризующего ландшафты современного общения, к рассказыванию историй, то есть от использования пассивных средств массовой информации к использованию все более активных средств массовой информации. В примерах, обсуждаемых автором, эмоциональная вовлеченность является неотъемлемой частью новых границ игр, которые выходят далеко за рамки развлекательных контекстов, нарушая общественно-политическое измерение «умных городов». То же самое произошло с многочисленными приложениями, которые отслеживали распространение вируса с помощью соблазнительной инфографики, заменяя общеизвестное беспокойство брокеров или игроков фондового рынка, которые просыпаются, чтобы проверить колебания цен на бумаге, новым беспокойством, которое отслеживает индексы заражения. Совместимость преобразований, вызванных платформами, нововведениями четвертой промышленной революции и новым пространственно-временным дизайном, необходимым благодаря распространению Covid-19, заставляет нас задуматься об адаптивных возможностях нового эмоционального капитализма.

\section{Вирус и мемы в современной коммуни- кации}

После многих лет эвфемистического употребления термин «вирусность» возвращается, чтобы разрушить нашу жизнь, уводя нас трав- 
мированно от виртуального царства, о котором мы говорили в течение некоторого времени, к более трагическому реальному, которое ускользает от нас и которым мы не можем управлять. Поскольку вирус перешел от прилагательного к существительному (видео, контент, мем), мы стали забывать о беспокойстве, тревоге и панике, которые может вызывать реальная вирусность или, скорее, биологическая вирусность, и которая сама усиливается СМИ и имеет социальную виральность. Предпандемический кризис вокруг Covid-19, который закрыл Италию, сделал доместикацию потребления, которую я называю «изоляцией» (Barile, 2020), еще более очевидной, поскольку пара предложений в Amazon, в которых ищут отбеливатель с презервативами, супермаркетами, которые грабят и, когда службы доставки и онлайн-приложений знакомств переживают наивысшую точку популярности. Вирус взламывает функционирование экспертных систем, офисов, учреждений и потребления, побуждая нас задуматься об их характере и функциях. Ничего не поделаешь, кроме как воспользоваться ситуацией, перейдя в интеллектуальный режим работы в ожидании из-за способности вируса преодолевать традиционные барьеры национальных государств. Это те границы, которые обладают огромной геополитической силой и которые по-разному, поощряют или препятствуют глобальному обороту товаров, людей, капитала, идей, технологий и т. д. Вирусное распространение само по себе парадоксально, поскольку оно расширяет границы, определяющие нации, города или сообщества. Эти границы имеют тенденцию противостоять форсированию вирусной передачи именно из-за прочных связей, которые защищают сообщество от вторжения внешнего врага. Однако, как только вирус проник через границу, используя слабые звенья и проникнув в однородное пространство сообщества, он начинает сеять там панику. Именно благодаря тому, что раньше было защитным элементом, а именно закрытием и однородностью сообщества, теперь появляется элемент культивирования и размножения инфекции. Как это произошло в Японии и Южной Корее, особенно в Тэгу, где религиозная секта Синчхонджи стала инкубационным кластером вируса, то есть суперраспространителем болезни. Или в Италии, первой европейской стране, которая закрыла свои связи с Китаем, но также и первая в Европе по количеству зараженных. Это привело к трагическому противовесу превращения одним махом из репеллеров в отбракованных, как в случае второго случая заражения Covid-19, обнаруженного в Африке 17 февраля 2020 года: техник, работавший на итальянского энергетического гиганта Eni. Это эмпирически опровергло общую тревогу, прозвучавшую из популистской партии «Лега» правого крыла Сальвини, которая обычно предупреждает о «вирусе», прибывающем на лодках иммигрантов. Корона считается суверенистическим вирусом, потому что она сначала подчеркивает барьеры между государствами, но гниль стирает все границы, построенные ретротопическим популистским видением: мы против других (а теперь мы превращаемся в других), люди против технократии (и теперь мы молим технократическую систему, чтобы спасти нас от инфекции, распространяемой людьми), харизма против компетентности (и теперь мы благодарны за то, что нас спасли навыки врачей, несмотря на хаотическую непредсказуемость популистских лидеров).

Следуя размышлениям Жана Бодрийяра о коде (Proto, 2019), именно благодаря открытию ДНК биологический дискурс пересекается и интегрируется с дискурсом вокруг общения. Как и в случае с отражением Уильяма Берроуза в его лекциях о творческом письме 1979 года, в которых он объясняет свою теорию языка как вируса. Для Уильяма Берроуза (2007) «слово» разработало и заразило биологический организм преалфабетического человека, определяя его изгнание из БОГА («Сад наслаждений»). Поэтому история человеческой цивилизации читается как огромное изменение отношения между телом и мыслью в том смысле, что мысль читается как чуждая телу сущность, которая действует почти сговорчиво по отношению к ней. Как и все самые известные вирусы, основная функция Слова состоит в том, чтобы воспроизводить себя, используя метаболизм организма-хозяина, чтобы копировать себя и создавать синтагматические цепи, которые имеют единственную цель - увековечить это представление. Берроуз вызывает электронную революцию, которая посредством деконструкции, преобразования глагола в образ («поскольку написанное слово является образом») возвращает Слово к его архаическому и магическому статусу. В гораздо большей степени, чем культурный эволюционизм Берроуза «деволюциониста», генетика Докинза с его «теорией мемов», генетика используется в качестве коммуникативной метафоры. Так же, как ген является базовой единицей генетической теории, мем представляет собой базовую концепцию, на которой построена «механика» Докинза. Во- 
преки мнению рекламодателей и ученых, распространение вирусов не является зависимой переменной технологических инноваций. Его изначальная природа связана с «устным» выражением сообщества, поскольку оно распространяется по социальным тканям, которые состоят из сильных и слабых звеньев. Однако сегодня виральность обязательно «исправляется» новыми СМИ.

Эмоциональный AI Эндрю Макстея «The Rise of Empathic Media» (2018) исследует не только платформы и устройства, которые развивают формы «эмоционального искусственного интеллекта», но также и все те инновации, которые смогли повысить эмоциональность человека в меркантильных терминах. По крайней мере, с момента изобретения в 1881 году гедонометра - механического устройства, измеряющего счастье - следуя по длинной волне бентамовских размышлений о капитализме и счастье. С тех пор мы могли почти утверждать, что все средства массовой информации пытались каким-то образом быть эмпатичными. Даже если настоящий эмпатический поворот наступит с появлением цифровых медиа, а затем и искусственного интеллекта. Среди эмпатических, «сделай сам» и «низко точных» носителей можно также включить «мем», распространяющийся вирусно благодаря алгоритмическим функциям профилирования и ранжирования. Задача \#iosonogiorgia (от «Io Sono Giorgia» или «Я - Джорджия») была, вероятно, самым мощным мемом в Италии в прошлом году, как с точки зрения распространения, так и с точки зрения участия пользователей. В нем участвовали люди, которые делали ремикс на речь, произнесенную на митинге в Риме правым популистским политиком Джорджией Мелони, когда она заявляла: «Я женщина, я мать, я христианин», что можно рассматривать как смешанную одновременную поддержку обеих женщин, как пол и традиционные семейные ценности. Простота мема, включающая в себя ранее существовавшую речь, наложенную поверх техно-музыки и в сочетании с существующими фильмами или телевизионными кадрами, сыграла по основной формуле: «Я есть...», которая во время кризиса субъекта и в то же время новой нарциссической одержимости для эго затрагивает глубокие нервы и пересекается между полиморфными публиками. Это утверждение идентичности, которое перезапускает роль субъекта, теперь разрушенного постмодерном, и затем расширяет дискурс на другие более общие и коллективные идентичности (опять же: женщина, мать, христианин). Именно те идентичности, которые продвинутая фаза глобализации пыталась исказить, руководствуясь новой посткартезианской эпистемологией: трансгендерные, постколониальные и постчеловеческие и т. д. Это утверждение о твердости современного суверенитета, которое начинается с современного субъекта, того самого, который парадоксально обосновал Просвещение и универсалистское видение, против которого выступает суверенный неокоммунизм. Мы здесь не для того, чтобы возобновить дебаты между теми, кто видит в умножении послания возможность контрастирования с продвижением нового права, и теми, кто считает, что это всего лишь дальнейшая реклама суверенистского видения (на полпути между Оскаром Уайльдом и культурой Jamming). То, что больше всего впечатляет и что мы могли бы избрать в качестве осевого принципа современного общения, - это стратегическая роль противоречия или, скорее, внутреннего противоречия. Фактически, суверенный мем почти метрически отмечен навязчивой центральностью эго, приобретающего коммуникативную силу именно благодаря его отрицанию. Таким образом, фрагменты дискурса Джорджии Мелони на Piazza di San Giovanni в Риме, основанной на музыке техно-рейв 90-х годов, порождают творческий и коллективный вызов снизу, которая пересекает все современное воображение. Невозможно перечислить каждую версию мема в обращении - от Красной Армии до группы бородатых мусульман, до охранника Дейенериса Таргариена из «Игры престолов», до Лавра и Харди, до знакомого техно-танцора викингов и до самого себя - уже мем. Многие в соцсетях поделились версией мема итальянской поющей звезды - мисс Кета, когда она пунктуально исполняет желания своих поклонников, произнося слова мема на концерте в Болонье. Множество предметов, которые, несмотря на самих себя, переосмысливают счет Мелони, лидера партии «Фрателли д’Италия» или (Братья Италии), создавая тем самым обходной путь по смыслу, превращая его в чистую форму. Знак, который не имеет ничего общего для общения, кроме пустоты бесконечного повторения, вместе с истерической веселостью, прослеживаемой на лице пользователя, и непрерывным опрокидыванием этой сильной идентичности, которая могла быть построена в многочисленных, неограниченных интерпретативных, перформативных возможностях, предлагаемых мемами.

Тема идентичности возвращается с высокомерием в современной культурной дискуссии, 
после оргии постмодернистских и глобалистских представлений, которые стремились ослабить ее, сделать ее релятивизированной, плюрализировать ее и, следовательно, опустошить ее первоначальное содержание (рассматривая его как плод фундаментальных эпистемических разрывов). Большая заслуга работы, проделанной Ф. Фукуямой (2018) в работе «Идентичность: требование достоинства и политика обиды», заключается именно в попытке вернуть дискурс об идентичности в результате «классической» политической философии, в чем предшествует деконструкции, проводимой постмодернистами. Совершенно идеологическая попытка, которая прежде всего усиливает преемственность, а не разрывы между западной современностью и тем, что происходит сегодня на наших глазах. По этой причине его экскурс иногда является частичным и включает некоторые важные ссылки, которые подготовили дискурс о кризисе современного субъекта. Особенно в предисловии ученый пытается уточнить различные очерки, из которых состоит эта книга, в свете самых последних исторических событий: от избрания Трампа до Брексита, проходящего через успех суперлидеров нелиберальных государств. Дрейф к новым формам нелиберального лидерства - это возможность представить концепцию, которая будет лучше развиваться во второй главе. Сократовский тимос понимается как та особая часть души, которая является местом «гнева и гордости» (ivi, p. 33). Особенно в его двух вариантах изотимии, или необходимости уважать других на равной основе, и мегалотимии, которая основана на желании быть признанным превосходящим других. Таким образом, рождение современных демократий описывается автором как устранение мегалотимии изотимией, в том числе благодаря левиафану, который, прибегая к сверхиндивидуальной силе, допускает мирное сосуществование между людьми. Но больше, чем в Гоббсе, речь Фукуямы постоянно возвращается к Сократу, чье философское открытие все еще имело бы большое значение. Во времена афинского философа достоинство было зарезервировано для стражей, то есть тех, кто, особенно в переосмыслении Платона, мог пожертвовать своей жизнью ради общества, и по этой причине их считали морально превосходящими торговцев. Миссия современных демократий состояла в том, чтобы поддержать изотимию в этом восходящем процессе эмансипации меньшинств, который, по мнению автора, достигает своего апогея в гегелевской идее всеобщего признания и в утверждении либеральных демократий, но сегодня им угрожает существенная деверсификация. То, что С. Хантингтон считал «третьей волной» демократий или их всемирным расширением в начале нового тысячелетия с тридцати пяти до более чем ста десяти, на самом деле является случайным и обратимым путем, который тревожит многих политологов. В том числе Ларри Даймонд с его идеей демократической «рецессии». Если на самом деле экспансивная, линейная, восходящая, глобализирующаяся динамика и т. д. демократических обществ гарантировала определенный динамический баланс между идентичностями (классовыми, этническими, религиозными, сексуальными и т. д.), достигая своего апогея с появлением постиндустриальных и глобализированных систем, то сегодня это равновесие нарушается под перекрестным огнем групп в борьбе за признание (как положительное, так и отрицательное). Фукуяма имеет дело с этой точкой, которая представляет собой центральный узел материи. Демократический кризис, который нас беспокоит, на самом деле проистекает из стремления к признанию, но это стремление к равному признанию легко может стать требованием признания превосходства группы. Динамика, которая, по моему мнению, вызывает переход от столкновения цивилизаций Хантингтона к столкновению невежеств или идентичностей, которое является одновременно внешним - думайте о миметической поляризации между суверенами и радикальным исламом - и внутренним в том смысле, что оно производит микрополяризации между группами, борющимися за всегда колеблющееся распознавание между изотимическим и мегалотимическим. Конфликт между этими двумя духами является пусковым механизмом современной политической поляризации. Новое политическое общение, опосредованное цифровой культурой, иногда подчеркивает, иногда пытается сдержать политическую поляризацию.

\section{Медиакультурное осмысление итальян- ской Lo-fi политики}

Современный успех мема в политике движет длинной волной «политизации» и поп-культуры в сети, которая отличается от более ранней политики поп-телевидения. Сила мема заключается в его распространяемости, благодаря которой подключенная аудитория не только визуализирует и транспонирует контент, но также присваивает, модифицирует, переосмысливает и перезапу- 
скает его с помощью новых вирусных процессов. Вот почему новая политика стремится распространяться в форме мема, ожидая, чтобы ее создали в определенном формате и возобновили в процессах спонтанного, творческого и неформального обмена.

Мы сталкиваемся с искаженным использованием культуры участия, вдохновляемой так называемыми «распространяемыми средствами массовой информации». Открытая, творческая и развлекательная массовая культура, которая рождается в онлайн-сообществах и использует систему ценностей, вращающуюся вокруг левых контркультур. C ло-фи (Lo-fi) политикой мы стали свидетелями участия культуры справа, с огромным и непредсказуемым успехом. После успеха онлайн-кампании Сальвини на итальянских всеобщих выборах 2018 года, в результате которой он стал министром внутренних дел на 3 месяца, вырос левый ответ в форме сардинского движения. «Сардины» - это массовое движение, которое организует флешмобы и акции протеста и заслуживает сдерживания цунами Сальвини на региональных выбоpax в Эмилии-Романье, благодаря в том числе 15-тысячному сильному флешмобу в Болонье в ноябре 2019 года. Спетая там популярная партизанская песня «Bella Ciao» дала понять, что эмпатические, партисипативные и вирусные медиа могут быть восстановлены слева, чтобы конкурировать с новой культурной гегемонией, поддерживаемой правыми популистами. Для этого стоит прочесть книгу Майка Уотсона «Могут ли левые научиться запоминать?: Adorno, видеоигры и странные вещи». Текст очищает инструменты критической теории, чтобы отразить современные отношения между искусством, культурной индустрией и политикой. Единственное отличие состоит в том, что в то время как для Адорно «капитализм в 1950-х годах был формой абстракции, которая притворялась рациональной (...), сегодня больше нет претензий рациональности (...), так что селфи, мем, Видео YouTube и инди-видео, возможно, представляют нашу попытку справиться с безумием нашего медиамира, взаимодействуя с его абсурдом и временно уходя в безопасное (и полностью сфабрикованное) пространство внутри него» (Watson M., 2019). Таким образом, настоящая проблема, над которой работает книга, заключается в «неспособности левых увидеть, как плохие, так и хорошие стороны в развитии Интернета, а также особую культуру производства и получения имиджа, которая его сопровождает». Книга каким-то образом предвосхитила вопрос, заданный позднее политической инициативой сардин, которые хотели ответить на гиперактивность Лиги миметическим и полемическим контрактивизмом. Новая вирусность сардин - это поздний, но очень эффективный ответ на проблему сегодняшней пассивности левых. Таким образом, желание привести воображение к власти, соединяя его с рациональностью абстрактных систем, может обрести новую жизненную силу в тактической вирусности нового политического общения (из которого сардины представляют возможную переходную фазу). Что левые могут извлечь из мемов, так это пирофы для разработки новых тактических и вирусных способов коммуникации, в то же время избегая перманентной эксплуатации массового феномена, осуществляемого неолиберальными институтами, партиями, компаниями и основными СМИ.

\section{References}

Barile N., (2020), Ontobranding as a destiny for Fashion: social polarization, grassroots creativity and the automation of everything, in Rafele A., Adalma F., a cura di, 2020, Cultural Studies in a digital age, San Diego University Press.

Burroughs, W. (2007), Word Virus: The William S. Burroughs Reader. William S. Burroughs. Grove Atlantic, New York.

Dawkins, R., (1976), The Selfish Gene, Oxford University Press.

Fukuyama, F. (2018), Identity: The Demand for Dignity and the Politics of Resentment, Farrar, Straus and Giroux, New York. McStay, A., 2018, Emotional AI. The rise of empathic media, London, Sage.

Proto, F. (2019), Baudrillard for Architects, London, Rutledge.

Saitō T. (2013), Hikikomori: Adolescence Without End, University of Minnesota Press.

Watson, M. (2019) Can the left can learn from mems. Adorno, Video Gaming, Stranger Things, Zero Books, Washington, USA. 